\title{
Harmonization of Green Open Space as Carbon Assimilator for Sustainable Environment of Transportation Sector and Steam Power Plant
}

\author{
Restu Juniah,* \\ ${ }^{1}$ Lecturer of Mining Engineering Department Sriwijaya University
}

\begin{abstract}
The environment has a function as a provider of raw materials (natural resources), aesthetics value and carbon assimilators. Emissions arising from the impact of activities in handmade environments such as transportation activities and steam power plant (SPP) activities may cause the environment to become unsustainable. The polluted air leads to a deterioration of the quality of both natural and social environment. Harmonization that occurs between green open space as the natural environment, transportation activities and steam power plant as handmade environment, and people as transport users and around SPP as social environment becomes sustainable. Reduced air pollution on the other hand, making the air absorbed by the community around the steam power plant is also better in quality. This makes the community of transportation users and steam power plant as social environment becomes sustainable since the impacts of the derivatives that arise on public health is being reduced. Thus, the harmonization between the three components of the living environment, namely Green Open Space (GOS) as the natural environment, transportation activities and steam power plant as an handmade environment, and the people as transportation users and around SPP as a social environment in the transportation sector and steam power plant.
\end{abstract}

Keywords: Emission, Natural environment (GOS), Handmade environment (transportation and steam power plant), Sustainable environment..

\begin{abstract}
Abstrak (Indonesian)
Lingkungan memiliki fungsi sebagai penyedia bahan mentah (sumber daya alam), nilai estetika dan asimilator karbon. Emisi yang timbul sebagai dampak kegiatan di lingkungan buatan seperti kegiatan transportasi dan kegiatan pembangkit listrik tenaga uap (PLTU) dapat menyebabkan lingkungan menjadi tidak berkelanjutan. Hal ini dikarenakan emisi menyebabkan udara menjadi tercemar. Udara yang tercemar mengakibatkan penurunan kualitas lingkungan alam dan lingkungan sosial. Harmonisasi yang terjadi antara ruang terbuka hijau sebagai lingkungan alam, kegiatan transportasi dan PLTU sebagai lingkungan buatan serta masyarakat penggguna transportasi dan sekitar PLTU sebagai lingkungan sosial menjadi berkelanjutan. Hal ini karena emisi yang timbul oleh kegiatan transportasi dan PLTU dapat diserap oleh tanaman yang terdapat pada ruang terbuka hijau. Penyerapan ini dapat mengurangi penurunan kualitas udara sehingga lingkungan alam tetap terjaga dan berkelanjutan. Berkurangnya pencemaran udara disisi lain, menjadikan kualitas udara lebih baik lagi sehingga udara yang diserap oleh masyarakat pengguna transportasi dan pejalan kaki serta sekitar PLTU juga dengan kualitas yang lebih baik lagi. Hal ini menjadikan masyarakat pengguna transportasi dan PLTU sebagai lingkungan sosial menjadi berkelanjutan. Hal ini dikarenakan terkuranginya dampak turunan yang timbul terhadap kesehatan masyarakat. Dengan demikian harmonisasi antara ketiga komponen lingkungan hidup yaitu RTH sebagai lingkungan alam, kegiatan trasportasi dan PLTU sebagai lingkungan buatan, dan masyarakat pengguna transportasi dan masyarakat yang berada sekitar PLTU sebagai lingkungan sosial menjadi sebuah keharusan untuk lingkungan yang berkelanjutan di sektor transportasi dan PLTU.
\end{abstract}

Katakunci: Emisi, Lingkungan alam (RTH), Lingkungan buatan (transportasi dan PLTU), Lingkungan berkelanjutan.

\section{Introduction}

Sustainable environment plays a role in realizing sustainable development. Sustainable development can only be realized if the environment where sustainable development activities. This is because sustainable development based on the three pillars of economic,

Article History:

Received: 6 October 2017

Accepteed: 8 January 2018

DOI: $10.22135 /$ sje.2018.3.1.43-46

*Corresponding Author: restu_juniah@yahoo.co.id social and environmental must be in line with environmentally sustainable on economic, social and ecological. Development that does not rely on one of these pillars will cause the environment is also unsustainable on the pillars.

Jakarta as one of the metropolitan cities in the world as the others such as Tokyo, New York, Moscow, Berlin, London and others is characterized by the multitude of multi-storey buildings, shopping centers, apartments. The metropolitan city is certainly followed by a dense population. The existence of these multi-storey buildings, shopping centers, apartments and crowded population requires energy. Energy requirements include electrical energy. Electrical energy is one of them generated from power plants. The main causes of air pollution other than stoves are power plants and petroleum-fueled vehicles ${ }^{[1]}$. Air pollution causes poor air quality. Air quality is worse especially in big cities of developing countries, so the quality of life of most urban dwellers is getting worse. Impacts arising from air pollution is the sky above it rarely looks clean from down until dusk as seen in Jakarta.

Combustion activities in steam power plants and the use of 
modes of transportation degrade environmental quality such as carbon dioxide and other air pollution emissions, resulting in noise, water pollution, disrupting natural physical conditions, and the environment. Burning fossil fuels causes the volume of $\mathrm{CO}_{2}$ emissions into the atmosphere to be very high. The carbon stock in the atmosphere is currently increasing by $0.04 \%$ or more than 3 million tonnes per year ${ }^{[2]}$. Environment experts point out carbon dioxide $\left(\mathrm{CO}_{2}\right)$ plays a major role in global warming, and this has become a global issue. $\mathrm{CO}_{2}$ gas is hazardous to the health of the community, especially the people who use motor vehicles and the people who live around the steam power plant. Both of these communities in an environmental perspective are part of the environmental component of the social environment. The impacts of the social environment may result in this environment being unsustainable. Based on this, it is important to examine the harmonization between motor vehicle users and pedestrians as well as communities living around SPP as a social environment with transportation activities and steam power plant as the built environment and GOS as the natural environment for sustainable environment needed in sustainable development.

\section{Methodology}

The method used is literature study using secondary data by perform processing and data analysis descriptively. Literature studies are used through references and journals related to the question of $\mathrm{CO}_{2}$ gas emissions. Processing and data analysis descriptively conducted to know the relationship and harmonization between green open space as the natural environment, transportation activities and steam power plant as handmade environment, and people as transport users and around SPP as social environment.

\section{Results and Discussion}

\subsection{Emissions of $\mathrm{CO}_{2}$ And Implementation Of Environmen- tal Components In Transportation Sector And Steam Power Plants}

Law No. 32 of 2009 on Environmental Protection and Management in article 1 mentions the protection and management of the environment as a systematic and integrated effort undertaken to preserve environmental functions and prevent the occurrence of pollution and / or environmental damage which includes planning, utilization, control, maintenance, supervision, and law enforcement. This article mentions systematic and integrated efforts undertaken to preserve environmental functions and prevent the occurrence of pollution and / or damage to the environment. The function of the environment is one of them as carbon assimilator and clean air provider ${ }^{[3]}$. Keeping the air clean means the same as keeping the environment function sustainable. Reducing the amount of $\mathrm{CO}_{2}$ emissions that are concentrated in the air is the same as preventing pollution and / or environmental damage. Emission reduction policies can be directed to the following ${ }^{[4]}$ :

1) Energy is used more efficiently

2) Fuel used with low carbon content

3) Enhancement of the use of renewable energy

4) Reduction activities runned with the use of privateowned vehicless

Emissions geographically distinguished into on-site emissions are emissions occurring at the site of activities / projects, and off-

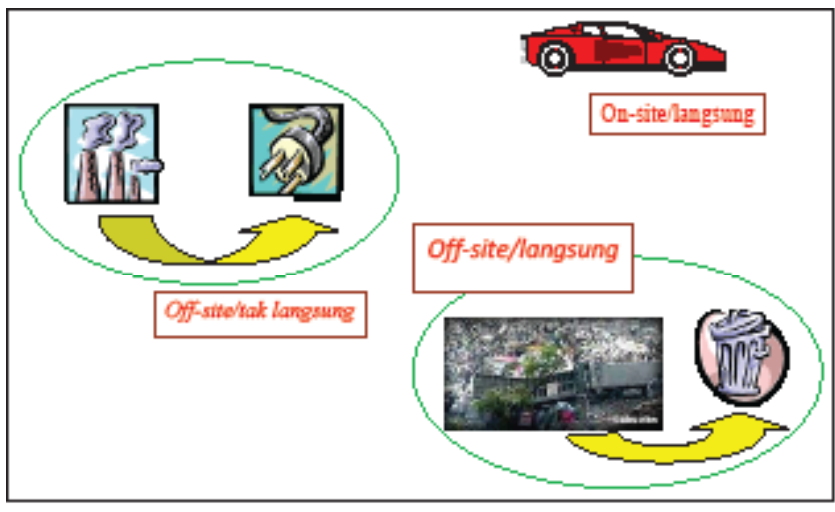

Figure 1. Category of Emission ${ }^{[4]}$

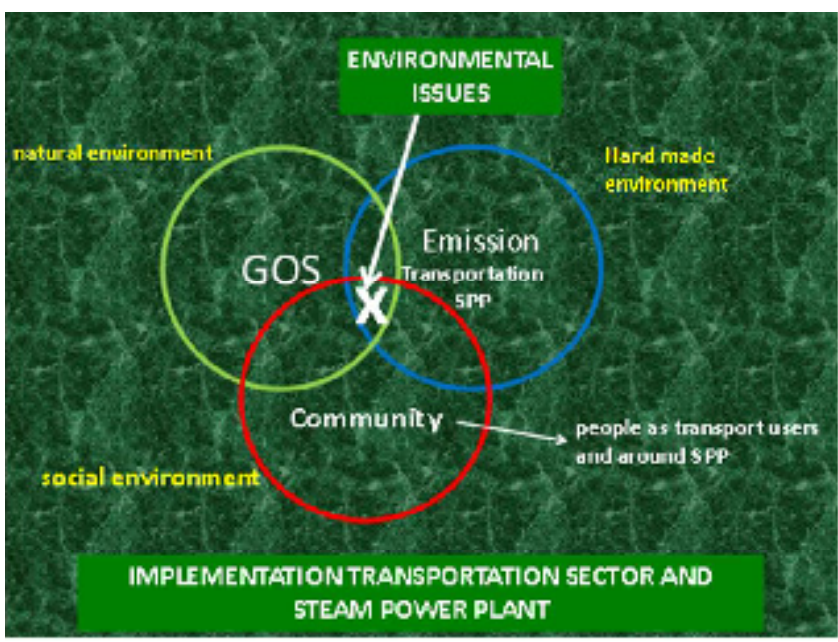

Figure 2. Implementation of Environmental Components of Transportation Sector and Steam Power Plant ${ }^{[5]}$

site emissions are emissions generated from activities elsewhere. Emission categories are illustrated in Figure 1.

Provision of green areas or Green Open Space (GOS) can restore air pollution. This is because GOS is a natural environment has a function as a carbon assimilator. Air is one of the most important elements of living things (humans, animals and plants). Everything need air to keep it alive. Therefore, the ambient air inhaled by living beings must be maintained in quality.

Air pollution is generally caused by the following two things: 1. Pollution that occurs naturally, such as the decay of dust waste that is flown by the wind and due to volcanic eruptions, and others; 2. Pollution due to human actions that are derived from moving sources (motor vehicles, aircraft, etc.) and the immovable source of industrial activity. Implementation of green open space as a natural environment, transportation emissions and steam power plant as an handmade environment, as well as transportation and people living around the SPP are shown in Figure 2.

\subsection{Harmonization of Green Open Space for Sustainable Envi- ronment Transportation Sector and Steam Power Plant.}

Because in everyday life we always use energy then energy is absolutely necessary. $\mathrm{CO}_{2}$ gas concentration and emissions in Indone- 


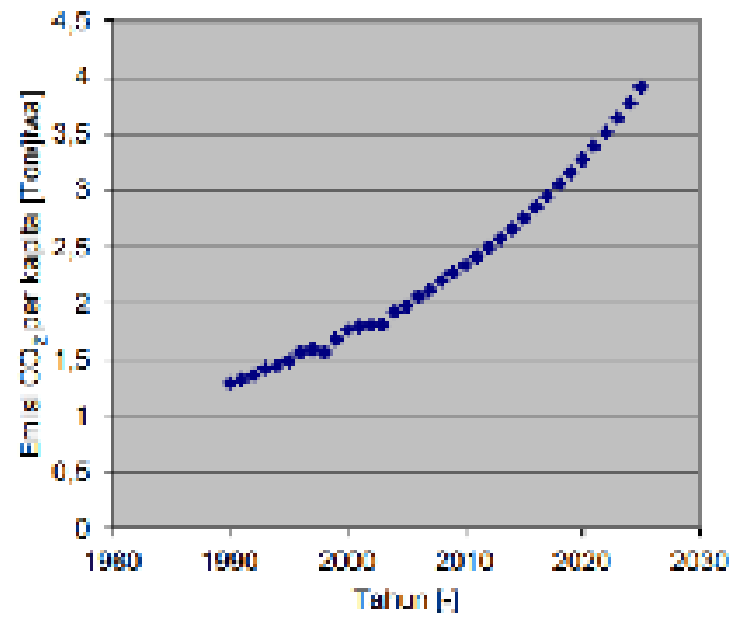

Figure 3. CO2 Emissions Per Capita From Energy Usage In Indonesia[6]

sia due to energy use tend to rise. The results of Samiaji found, for the period 2004-2010 there was an increase from 373 to $383 \mathrm{ppm}^{[6]}$. $\mathrm{CO}_{2}$ emissions per capita from energy consumption in Indonesia is shown in Figure 3.

Based on the figure above shows that $\mathrm{CO}_{2}$ emissions per capita of energy consumption in Indonesia continues to increase along with the increase of time. This can be understood, with the increase of population every year, the addition of apartments, buildings rise then the need for energy is also increasing.

Transportation technology and power generation on the one hand still rely on fuels derived from non renewable resources such as oil and coal, while on the other side fuels derived from renewable resources have not been fully replaced. Fossil fuels derived from the largest and major contributors to $\mathrm{CO}_{2}$ emissions.

$\mathrm{CO}_{2}$ emissions generated by motor vehicles and steam power plants are influenced by several factors. Factors affecting $\mathrm{CO}_{2}$ emissions by SPP are the quality of the coal used, the efficiency and the economic life of the equipment operation, while the motor vehicle is affected by the number and type of vehicles and fuel used ${ }^{[2,7]}$.

$\mathrm{CO}_{2}$ emissions of the world's transport sector in 2004 were about 12 percent of the total, and land transportation accounted for 74 percent of these emissions. $\mathrm{CO}_{2}$ emissions of motor vehicles in the city of Denpasar in 2012 as many as 20,339.17 tons / year $648.49 \mathrm{~km}$ lead to $\mathrm{CO}_{2}$ emissions in 2011 of $283,650.43$ tons $/$ year ${ }^{[8]}$, shown in Figure 4. $\mathrm{CO}_{2}$ emissions from the transport sector are expected to increase from 72 million tons in 2010 to 232 million tons in 2030 $0^{[9]}$.Motor vehicle emissions span 2000-2025.

Based on Figure 4 below shows that the type of motor vehicle affects the amount of emissions generated. The car occupies the first sequence of $\mathrm{CO}_{2}$ emission contributor, followed by bus in second, motorcycle in third, and the smallest contributor of emission is truck. The results of Hidayat's research also found that the type of vehicle has an effect on the amount of $\mathrm{CO}_{2}$ emissions generated as presented in Table 1 .

Rizki et al founded that $\mathrm{CO}_{2}$ emissions generated by SPP Suralaya Unit 1-7 by the the year 2010-2014 amounted to $112,165,480$ tons ${ }^{[2]}$. $\mathrm{CO}_{2}$ generated SPP Banten, Indramayu, and Rembang produce of 16 thousand kTon ${ }^{[1]}$. Coal and Indralaya's steam generating plants produce $\mathrm{CO} 2$ for $514,185.7$ tons $\mathrm{CO} 2 \mathrm{eq} /$ year and

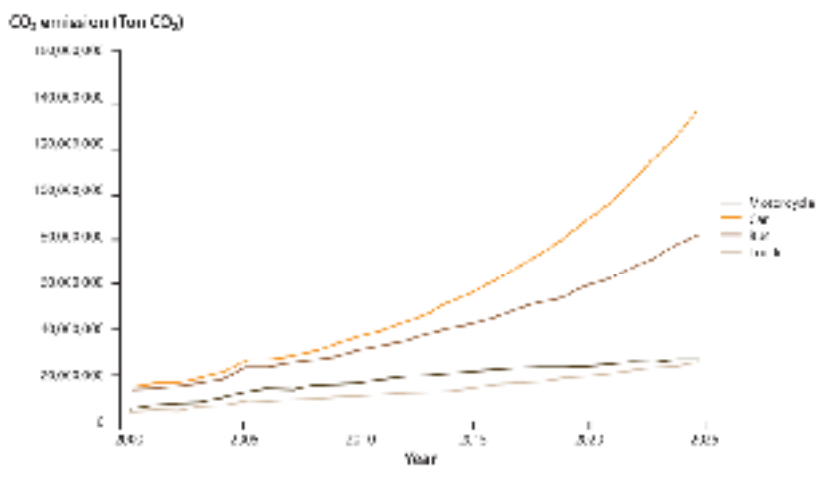

Figure 4. Motor Vehicle CO2 emissions Range year 2000-2025 ${ }^{[9]}$

Table 1. $\mathrm{CO}_{2}$ Emissions Some Types of Motor Vehicles ${ }^{[10]}$

\begin{tabular}{|c|c|c|}
\hline No & Transportation type & Emission CO2 $(\mathrm{Kg} /$ hour $)$ \\
\hline 1 & Passenger car & 1521.24 \\
\hline 2 & Medium vehicle & 385.24 \\
\hline 3 & Heavy vehicle & 192.37 \\
\hline 4 & Motorcycle & 3340.67 \\
\hline \multicolumn{2}{|c|}{ Total } & 5439.67 \\
\hline
\end{tabular}

$807,076.3$ tons $\mathrm{CO} 2 \mathrm{eq} /$ year respectively ${ }^{[12]}$. Maya in his research found the ability of $\mathrm{CO}_{2}$ emission absorption by green open space in Keramasan and Indralaya sectors is respectively at 1,503 ton $\mathrm{C}$ and 92,5 tonC. The results of Maya research indicate if the ability of green space as the natural environment in the location of steam power plant and Indralaya to absorb far under the emissions produced by the steam power plant as the built environment. Hidayat studies found if $\mathrm{CO}_{2}$ uptake by trees along the streets is of $1,506,662 \mathrm{~kg}$. These results indicate if the vegetation present in the space belonging to the road has a low uptake. Therefore, vegetation that has a high capability to absorb carbon is required. The results of this study are in line with the Liputo study that found if the type of vegetation affect the size of the emissions absorbed.

Based on the results of Maya's research, the polluted air can be recover with green open space, in necessary to increase the extent of green open space ecological functions of air pollution restoration, so that the natural environment can be sustainable. Liputo's (2015) study, as Maya's research, found if GOS has the ability to absorb emissions from motor vehicle emissions. This absorbing ability is influenced by the extent, distribution, density and type of green space.

Controlling traffic volume as an handmade environment and improving the distribution of green open space and the type of vegetation as the natural environment as well as the community of transport users as a social environment is expected to encourage the use of transportation as a environmentally friendly environment that creates harmonization among the three.

Harmonization that occurs between the three components of the environment that is green space as the natural environment, transport emissions and steam power plant as the handmade environment and the community of transport users and steam power plants as a social environment can be sustainable if the availability of green space as a carbon assimilator for environment sustainable in accordance with the minimum target (30\% in Law Number 26 Year 2007 on Spatial This is because the nature of the vegetation in 
green open space as carbon assimilator must be able to absorb $\mathrm{CO}_{2}$ gas produced by motor vehicles and steam power plant as much as possible in accordance with the above minimum target.

\section{Conclusion}

The environment will be sustainable if the three components of the environment (the natural environment, the handmade environment, and the social environment in the interaction can harmonize harmonically.) The green open space, the type of vegetation found in green open space has an effect on the size of carbon emissions emitted by motor vehicles and steam power plants. The GOS area still has not fulfilled the target of at least $30 \%$ as regulated in Law No. 26 of year 2007 About Spatial and vegetation type contained in green space not yet suitable for high absorption category so that the carbon uptake in Steam Power Plant and transportation sector is still low, therefore $\mathrm{CO} 2$ emission generated by the transportation sector and Steam Power Generation as an handmade environment, the Green Open Space as a natural environment, as well as the community of transport users and communities living around the steam power plant should harmonize in harmony which means the availability of green space must meet at least $30 \%$ which is regulated in the Law of Spatial for emissions generated by the transportation sector and steam power plants as an handmade environment can be absorbed optimally so that the environment can be sustainable. Communities that are social environments should reduce $\mathrm{CO} 2$ emissions through the use of transportation modes and steam power plant activities.

\section{References}

Astra, I. M.. "Energy And Its Impact On The Environment". Journal of Meteorology and Geophysics, Vol. 11, pp. 131-139. Nov. 2010.

Rizki, D. F. H. Yulinawati and M. D. S. Silalahi."Study of Inventory And Estimation of Carbon Dioxide Emission Reduction Effort In SPP Suralaya Unit 1-7”. National Seminar of Schol- ars, 2016.

Sambas, Wirakusumah. Fundamentals of Ecology, Supporting Knowledge Environmental sciences. Jakarta: Indonesia University (UIPress). 2003.

Suhedi, F." $\mathrm{CO}_{2}$ emissions from Domestic Energy Consumption". R \& D Center. sim.nilim.go.jp/GE/SEMI6/Paper/06-FEN.doc, 2016.

Juniah, R."Cooperation of Perhapi with Master Program and Mining Engineering Department Unsri", Working Group Week IV Perhapi 2017, Palembang 12-13 October 2017.

Samiaji, T."CO2 Gas in the Territory of Indonesia". Vol. 12, PP: 68-75, 2011.

Liputo, S. "Model of Emission and Quality Relationship of Urban Green Areas: A Study of the Relation of the Distribution of Primary Pollutants and the Quality of Green Areas in DKI Jakarta”. Dissertation, Environmental Science Program UI. Jakarta, 2014.

Nurdjanah, N."CO2 Emissions Due to Motor Vehicles In Denpasar City". Journal of Land Transport Research, Vol. 17, PP: 1-14, March 2015.

Center for Climate Change and Multilateral Financing Policy (PKPPIM) Ministry of Finance of the Republic of Indonesia. Fiscal Policy Reform Option to Support Control of Exhaust Emissions from Motor Vehicles. Jakarta, 2015.

Hidayat, E."Absorption of $\mathrm{CO}_{2}$ Emission from Motor Vehicles Through Vegetation Technologies". The Owned Room of Journal Street Social Work Public, Vol.5, July 2013.

Budi, R. F. S. \& Suparman. "Calculation of $\mathrm{CO}_{2}$ Emission Factor for Coal and Nuclear Power Plant". Journal of nuclear energy development, Vol 15, 2013.

Maya, A.A., D Setyawan and I. Iskandar.'Estimation of Carbon Reserves as Green Indicators in Power Plant Areas". Journal of Environment and Development, Vol. 2, 2016. 